\title{
Identification of Red Sea lionfish venom-protein and assessing its anti- cancer efficacy
}

\author{
Ahmed A. Sayed ${ }^{1 *}$, Mai Yousery ${ }^{2}$ and Justin Grubich ${ }^{2}$ \\ ${ }^{1}$ Department of Biochemistry, Faculty of Science, Ain Shams University, Cairo, 11566, Egypt, \\ ${ }^{2}$ Department of Biology, AUC, Cairo, Egypt
}

\section{A R T I C L E I N F O}

Article history:

Received 09 April 2016

Accepted 23 June 2016

Keywords:

Red Sea;

Lionfish;

Venomous spines;

Anti-cancer;

Cytotoxic.

\begin{abstract}
A B S T R A C T
Pterois miles, the common lionfish, is one of the most abundant venomous fishes that inhabit the Egyptian Red Sea. To date all the published biotechnology research is done on a sister species, Pterois volitans, and none is done on the native Red Sea lionfish, Pterois miles. The aim of this study is to address this gap in the lionfish research through investigating the identity of the venom protein of the Red Sea lionfish, Pterois miles, and to assess its anti-cancer efficacy using the HepG2 cancer cell line. The venom identity was scrutinized by comparing the specific protein composition of the venomous spines of the Pterois miles to that of the non-venomous caudal fin rays (the tail). A $75 \mathrm{kDa}$ protein band, present only in the venomous spine, and absent in the caudal fin rays, revealed strong molecular weight similarity to the venom protein of the sister lionfish species, Pterois volitans. The crude venomous spine protein homogenate showed an anticancer effect on the HepG2 cancer cell lines up to very low concentrations reaching $7.5 \mu \mathrm{g} / \mathrm{ml}$. On the contrary, the tail crude protein homogenate did not have any activity. Using size exclusion chromatography fractionation, only those fractions containing the purported venom protein band in the spine homogenate demonstrated cytotoxic effects on HepG2 cancer cell lines. These promising results suggest that the venom protein of the Red Sea lionfish Pterois miles could have a potent cytotoxic effect that worth more investigation.
\end{abstract}

of natural pharmacological and anti-cancer compounds ${ }^{[8]}$. Toxicity of these venomous fishes indicates potent physiological activity. Therefore, it is quite possible that toxic substances in piscine venom could yield valuable biomedical compounds [9]. Catfishes, Stingrays, Toadfishes, Stone fishes and Lionfishes are among the well documented venomous fishes ${ }^{[\mathbf{8 , 1 0 ]}}$. Lionfishes of the Family Scorpaenidae are one of the most well-known venomous fishes that inhabit the coral reefs of the unexplored Red Sea, which represents one of the most diverse marine environments in the world ${ }^{[11]}$. At least six species of lionfishes of the subfamily Pteroinae have been identified in the Red Sea. These include the relatively abundant Pterois miles, Pterois radiata and Pterois antennata ${ }^{[12]}$.

Pterois miles of the Red Sea and its venom is the focus of this study. Pterois miles and its sister species Pterois volitans ${ }^{[13]}$ were found to be two genetically distinct species using mitochondrial DNA analyses ${ }^{[14,15]}$. Spines are the only anatomical structure of the lionfish that secretes venom, unlike fin rays which form the caudal fin (tail). The venom is secreted in the glandular tissue

\footnotetext{
* Corresponding author.

E-mail address: aasayed@sci.asu.edu.eg
} 
located in eighteen long venomous spines; thirteen dorsal, three anal, and two pelvic ${ }^{[16]}$.

The physiological effects of venom homogenates of the lionfish species Pterois volitans have been the subject of several studies since the 1950's ${ }^{[16-18]}$. An antitumor activity was attributed to the lionfish species Pterois volitans. The venom homogenate was shown to have hepatoprotective and antimetastatic effects on Ehrlich's ascites carcinoma xenografted mice ${ }^{[18]}$. In this study, some light has been shed for the first time on the protein profile of the crude venom of Pterois miles. Inspired by the venom homogenate's anti-tumor activity of the sister species, Pterois volitans, the cytotoxicity of the Pterois miles' venom protein suggested to be at the $75 \mathrm{kDa}$ range was tested on HepG2 cells.

\section{Materials and Methods}

Preparation and quantification of the protein homogenates

Live specimens of Pterois miles collected from the Red Sea, Egypt were purchased, from a local aquarium store. The venomous dorsal spines, as well as, the nonvenomous caudal fin rays (tail) were cut off, using sterilized clippers, and were kept in $10 \%$ glycerol solution at $-80^{\circ} \mathrm{C}$.Venomous dorsal spines only are used in this study. Throughout the text, the venomous dorsal spines are referred to as spines, while the caudal fin rays are referred to as tails. Both the crude protein homogenates from the venomous spines and the nonvenomous tail were prepared according to ${ }^{[17]}$. Briefly, the frozen samples were thawed and ground in $10 \%$ glycerol using a chilled mortar and pestle. The resultant suspension was then centrifuged at $7000 \mathrm{xg}$ for $10 \mathrm{~min}$ where the supernatant containing the proteins was collected and the pellet was re-suspended in 10\% glycerol and re-centrifuged. The supernatants were pooled and quantified using the Bio-Rad DC protein assay (Cat No. 500-0112).

\section{SDS-PAGE}

The crude protein homogenates of the venomous spine, the non-venomous tail and the size exclusion chromatography protein fractions obtained from both crude protein homogenates were separated on $12 \%$ SDS gels. SDS-PAGE was performed for the spine and tail protein homogenates obtained from at least 20 different specimens. Electrophoresis was done using a Bio-Rad Mini-PROTEAN® Tetra Cell. SDS gels were stained using Coomassie Brilliant R-250. Preparation of the SDS gels, protein samples and buffers as well as the electrophoresis procedure were done as described by ${ }^{[19]}$. Molecular weight ladder was used as a reference; Page Ruler TM Plus Prestained Protein Ladder (Fermentas Cat. No. SM1811).

\section{Mass spectrometry}

Mass spectrometry was performed to the $\sim 75 \mathrm{kDa}$ excised gel band from the SDS gel of one of the spine protein homogenates. The excised gel band was stored in a 1:1 diluted de-stain solution. The de-stain solution used is formed of $70 \%$ distilled water, $25 \%$ methanol and 5\% acetic acid. The Mass Spectrometric analysis of this protein band was done at the core facility of the Protein and Science, Biotechnology Carver Center, University of Illinois, USA. The methodology followed by the facility is detailed in the following paragraph. The in gel digestion was carried out as follows; Gel slices were destained, digested in $25 \mu \mathrm{l}$ of sequencing grade Trypsin $(12.5 \mathrm{ng} / \mu \mathrm{l}$ in $25 \mathrm{mM}$ ammonium bicarbonate, G-Biosciences St. Louis, MO) using a CEM Discover Microwave Digestor (Mathews, NC) for 15 minutes at $55^{\circ} \mathrm{C}(50 \mathrm{~W})$ and the peptides were then extracted using $50 \%$ acetonitrile with 5\% formic acid, dried using a Savant SpeedVac and suspended in $13 \mu \mathrm{l}$ of $5 \%$ acetonitrile containing $0.1 \%$ formic acid. Afterwards, a volume of $10 \mu \mathrm{l}$ of sample was used for mass spectrometry analysis. The mass spectrometer used was a Waters quadrupole time-of-flight mass spectrometer (QToF) connected to a Waters nano Acquity UPLC. The column used was Waters Atlantis C-18 $(0.03 \mathrm{~mm}$ particle, $0.075 \mathrm{~mm} \times 150 \mathrm{~mm}$ ). Flow rate was at $250 \mathrm{nl}$ per minute. Peptides were eluted using a linear gradient of water/acetonitrile $(0-60 \%)$ containing $0.1 \%$ formic acid in 60 minutes. The mass spectrometer was set for data dependent acquisition, $\mathrm{ms} / \mathrm{ms}$ was performed on the most abundant four peaks at any given time. Data analysis was done using Waters Protein Lynx Global Server 2.2.5, Mascot (Matrix Sciences) and Blasted against NCBI NR database.

\section{Size exclusion chromatography (SEC)}

Protein contents of both the crude protein homogenates from the venomous spines and the non-venomous tail were separated using the Akta Purifier (GE HealthCare, USA). Samples injected in the Akta Purifier were constantly having the concentration of $1 \mathrm{mg} / \mathrm{ml}$. One $\mathrm{ml}$ of each of the samples (homogenates) was applied to Superde ${ }^{\mathrm{TM}} 75$ prep grade column (GE HealthCare Cat. No. 17-1044-01). The column was equilibrated using 50 $\mathrm{mM}$ sodium phosphate buffer at a flow rate of 0.05 $\mathrm{ml} / \mathrm{min}$ overnight. Upon elution, the same buffer was used but at a flow rate of $0.25 \mathrm{ml} / \mathrm{min}$. The elution process resulted in 48 fractions for each of the two protein homogenate types; each of the fractions is $0.5 \mathrm{ml}$. Fraction names in order are as follows: A1-A12, B1B12, C1-C12 and D1-D12. The SEC was done for one representative venomous spine protein homogenate and for one representative tail protein homogenate from a single lionfish specimen.

\section{Cell culture}

A human hepatocellular liver carcinoma (HepG2) cell line was used for the in vitro testing of the protein crude homogenates, and fractions, cytotoxicities. HepG2 cells were used for its advantages in testing the cytotoxicity of compounds ${ }^{1}$ as well as proving useful before in testing a marine jellyfish venom cytotoxicity ${ }^{[20]}$. HepG2 cancer cells were incubated at $5 \% \mathrm{CO}_{2}$ at $37^{\circ} \mathrm{C}$ and were kept in a complete medium formed of RPMI 1640 (Lonza, USA), $10 \%$ Fetal Bovine Serum (FBS- inactivated at $37^{\circ} \mathrm{C}$ ) and $5 \%$ Penicillin-Streptomycin (Lonza, USA). For testing the crude protein homogenates, spine or tail, cells were seeded at a fixed count of $4 \times 10^{4}$ cells/well 
in a 96-well plate. Both crude homogenates, the spine and the tail, were incubated with the HepG2 cells, using different concentrations. Control: HepG2 cells incubated in $10 \%$ glycerol in complete media. For testing the protein fractions, produced from SEC of both protein homogenates, cells were also seeded at a fixed count of 3 X $10^{4}$ cells/well. Control: HepG2 cells incubated in $10 \%$ glycerol with $50 \mathrm{mM}$ sodium phosphate buffer in complete media. After seeding and before testing the cytotoxic effects of any of the samples, the cells were cultured at $5 \% \mathrm{CO}_{2}$ at $37^{\circ} \mathrm{C}$ for $24 \mathrm{hrs}$ to rule out the effects of any stress on the cells' viability and allow for the cells' attachment. Twenty four hour incubation with the protein homogenates, and fractions, were also achieved before assessing its effect on the cells. Viable cell count was determined by a haemocytometer, using trypan blue staining (Hausser Scientific, USA). Morphological changes and signs of cell death after the addition of any of the protein crude homogenates, or protein fractions, were observed using an inverted microscope (Olympus 1X70, USA). The cells were observed microscopically to detect any deviation from the normal state of the HepG2 cells as they are known for their epithelial nature ${ }^{[21]}$.

The fractions tested for cytotoxicity were the result of fractionating only one representative homogenate for each of the spine or tail. The same volume was used on testing any of the fractions, the spine or tail fractions. Each fraction being tested is incubated with the cells for 48 hours before assessing the cell viability, which reflects the level of activity of the protein fractions.

\section{MTT Cytotoxicity Assay}

The cytotoxic effects of the crude protein homogenates as well as the effect of the protein fractions on the HepG2 cells viability were determined using the MTT colorimetric assay. MTT (Serva, Germany) is the 3-(4, 5-dimethylthiazolyl-2)-2, 5-diphenyltetrazolium bromide which originally has a yellow color. The assay depends on the capability of the viable cells to capture the watersoluble tetrazolium yellow colored compound and reduce it in a mitochondrial-dependant manner into a water-insoluble purple formazan product ${ }^{[22]}$. After incubation with the protein homogenates or the protein fractions, the old media containing the sample were removed from the wells and the cells were replenished with $120 \mu \mathrm{l}$ complete media. MTT, $5 \mathrm{mg} / \mathrm{ml}$, (Serva, Germany) of volume $24 \mu \mathrm{l}$ is added to each well. After incubation for 3 hours at $37^{\circ} \mathrm{C}$ and $5 \% \mathrm{CO}_{2}$, the media containing the MTT were removed and $100 \mu$ of DMSO (Sigma-Aldrich, USA) were added to solubilize the purple formazan product if formed. The absorbance was measured using the FLUOstar OPTIMA microplate reader (BMG LabTech, Germany) at $590 \mathrm{~nm}$. The absorbance reading is the mean of at least three independent readings

$$
\% \text { Cell Viability }=\frac{\text { Absorbance of sample }}{\text { Absorbance of control }} \times 100
$$

\section{Statistical Analysis}

Raw data, the absorbance of each fraction, was corrected by subtraction of the blank readings (media without any sample). The corrected raw data were analyzed using the statistical software program, R@ version 2.14.1 (201112-22). $\mathrm{P}$ values were computed using ANOVA to detect for significance differences between the sample means (spine and tail fractions) and the control. $\mathrm{P}<0.05$ was considered to be statistically significant.

\section{Results}

Protein profile of the venomous spines versus the non-venomous tail

SDS PAGE was used to compare the differential protein expression patterns of both of the crude protein homogenates isolated from the venomous dorsal spines and the non-venomous caudal fin (tail) of the Red Sea lionfish species Pterois miles. As shown in Figure 1, the protein patterns for both homogenates showed in general some degree of similarity. In the crude spine protein homogenate, two obvious distinct bands are found at the molecular weights of $\sim 35 \mathrm{kDa}$ and $\sim 75 \mathrm{kDa}$ (Fig. 1). These two bands are specifically and solely present in all the spine crude protein homogenates tested but absent in all the tail crude protein homogenates tested. Based on the fact that the spines are venomous and that the tail is not, then the venom protein is probably one of the two proteins that are exclusively found in the spine protein homogenate. The $\sim 75 \mathrm{kDa}$ band was chosen for further mass spectrometric analysis based on previous reports of identified venom protein of the same size from sister species Pterois volitans and Pterois antennata ${ }^{[10]}$.

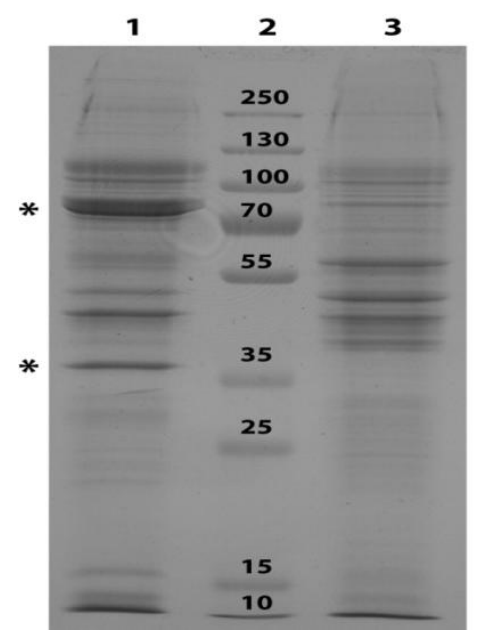

Fig (1): Protein analysis of Pterois mile crude homogenates. $12 \%$ SDS-PAGE analysis for Pterois miles. Lanes (1) Crude venom protein homogenate showing the purported venom band at $\sim 75 \mathrm{kDa}(960 \mu \mathrm{g} / \mathrm{ml})$; (2) BioRad pre-stained ladder SM1811; (3) tail protein homogenate $(960 \mu \mathrm{g} / \mathrm{ml}) .(*)$ : Indicate two distinct bands are found at the molecular weights of $\sim 35 \mathrm{kDa}$ and $\sim 75 \mathrm{kDa}$ at the crude venom protein homogenate.

Venomous spines and non-venomous tail; A Proof of Concept

Mass spectrometry (MS) was used to identify the excised $75 \mathrm{kDa}$ band of the Pterois miles specimen, characteristic to the spine crude protein homogenate. 
On performing MALDI-TOF MS, a peptide mass fingerprint spectrum (PMF) was produced for this band (Fig. 2). Mascot search tool of Matrix Sciences was used to search the NCBI database for a protein with matching PMF. The Mascot search gave three hits for the protein band under study: Pterois antennata toxin subunit alpha, Pterois volitans toxin subunit alpha and Pterois antennata toxin subunit beta. The protein summary report showed that two of these hits, Pterois antennata toxin subunit alpha and Pterois volitans toxin subunit alpha, were identified with a protein score of 111, while the third, Pterois antennata toxin subunit beta, was identified with a score of 80 . According to Mascot, protein scores greater than 84 are significant $(\mathrm{p}<0.05)$. It is worth mentioning that two unique peptides of Pterois miles sample in the PMF were matched to both the Pterois antennata toxin subunit alpha and the Pterois volitans toxin subunit alpha with sequence coverage of $4 \%$. Subsequently, these two Pterois miles peptides were chosen for fragmentation and MALDI-TOF/TOF (MS/MS) was performed. According to Mascot score, individual ion scores greater than 57 indicates identity or extensive homology. In the Pterois miles sample peptide summary report, one peptide was shown to be significant with an ion score of 72 , while the other was not significant having ion score of 20. Protein hits to Pterois antennata toxin subunit alpha and $P$. volitans toxin subunit alpha also revealed a similar high score, 90. These two peptide sequences were also blasted using blastp against the non-redundant (nr) protein database $(14,206,148$ sequences; 4, 868, 102,627 residues). Interestingly, both peptides of the Pterois miles sample were shown to be unique to the Pterois fish toxins. In general, mass spectrometry analysis of the Pterois miles sample showed strong homology to the Pterois volitans and Pterois antennata toxins as consistent with the phylogenetic relationships.

Cytotoxic effect of the Pterois miles crude spine protein homogenate on HepG2 cells

Cell cultures of HepG2 followed by MTT assay were used to assess the cytotoxicity of the crude protein homogenates. Spine crude protein homogenate concentrations of $1000 \mu \mathrm{g} / \mathrm{ml}$ and $500 \mu \mathrm{g} / \mathrm{ml}$ caused the death of $78 \%(p<0.001)$ and $59 \%(p<0.001)$ of the cells, respectively. Interestingly, concentrations as low as 7.8 $\mathrm{g} / \mathrm{ml}$ and $3.9 \mathrm{~g} / \mathrm{ml}$ of the crude spine homogenate continued to cause a significant percentage of cell death. The above mentioned relatively low concentrations caused the death of approximately 50\% ( $<<0.001)$ and $42 \%(\mathrm{p}<0.001)$ of the cells, respectively (Fig. 3). HepG2 cell death was also morphologically apparent when the cells were treated with the same protein concentrations. The dying HepG2 cells lost attachment and had roundshaped morphology unlike the control cells with apparently normal epithelial shapes (Fig. 4).However, no cytotoxic effects were shown on the HepG2 cells upon investigating the cytotoxicity of the crude tail protein homogenates (Fig. 4).

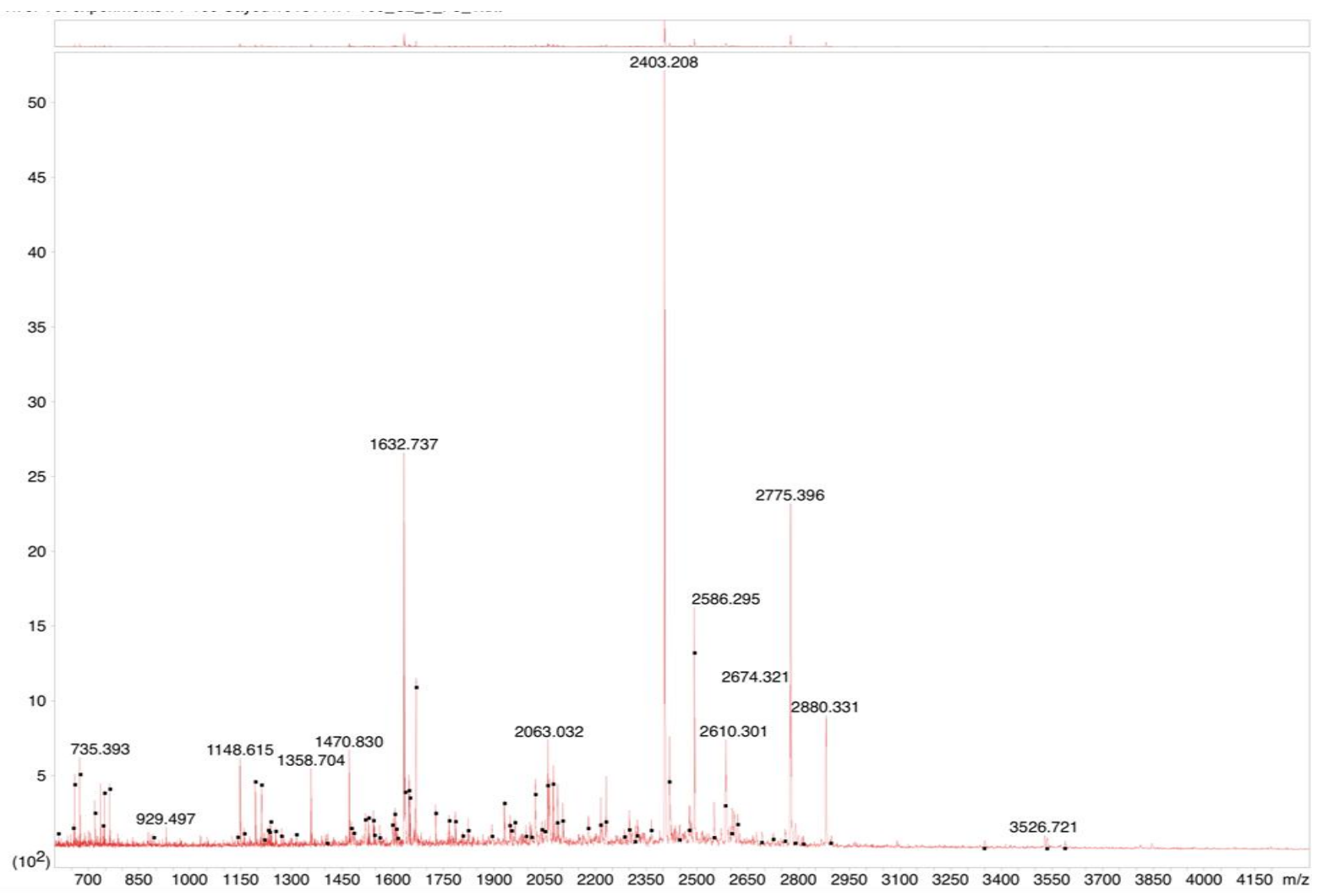

Fig (2): Peptide Mass fingerprint of the approximately $75-\mathrm{kDa}$ excised spine protein band. X-axis showing the $\mathrm{m} / \mathrm{z}$ ratio (mass/charge ratio) while the y-axis showing the abundance of different fragments. 


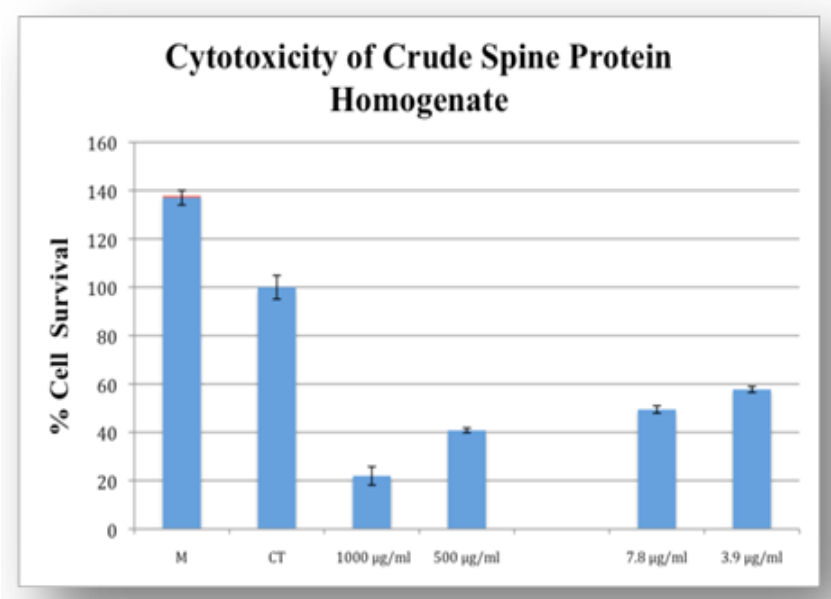

Fig (3): MTT assay showing the cytotoxicity of the crude spine protein homogenate of the same individual sample. The graph represents cell survival of the HepG2 cells after exposure to different concentrations of the crude venom protein homogenate, $1000 \mu \mathrm{g} / \mathrm{ml}$ and $500 \mu \mathrm{g} / \mathrm{ml}, 7.8 \mu \mathrm{g} / \mathrm{ml}$ and $3.9 \mu \mathrm{g} / \mathrm{ml}$. M; cell survival percentage in the presence of media only, CT; cell survival percentage of the control (50mM sodium phosphate buffer and $10 \%$ glycerol). Cell survival percentages among the venom homogenate concentrations were significantly different from $\mathrm{M}$ and $\mathrm{CT}$ in one-way ANOVA $(p<0.001)$. Values are the means \pm SD.

Fractionation of the Pterois miles' crude homogenates of the spine and tail revealing different protein composition in the fractions

Proteins of different sizes appeared in different fractions upon performing size exclusion chromatography for each of the crude homogenates, the spine and the tail. Both homogenates yielded 48 fractions after the elution was completed. For both the spine and the tail homogenates, the different proteins were observed starting from fraction A10. On comparing the resulting chromatogram of the spine protein homogenate (Fig. 5A) to that of the tail protein homogenate (Fig. 5B), difference in their protein patterns was obvious which was consistent with the early SDS PAGE gels (Fig. 1). On observing the chromatograms, two distinct regions were different. The first region is the high molecular weight region consisting of the fractions B1-B9. The second region is the lower molecular weight region which consists of the fractions C3-D3 (Figs. 5A \& B). Based on the findings illustrated in section 3.2 that proposed the Pterois miles'venom protein to be at the $\sim 75 \mathrm{kDa}$ range, the higher molecular weight region consisting of fractions B1-B9 was given more attention. SDS PAGE was done to confirm the protein content of the fractions B1-B9 in the spine homogenate and the tail homogenate (Figs. 6A, B \& C). Only fractions B1-B6 produced from the spine protein homogenate showed an obvious protein band at $\sim 75 \mathrm{kDa}$ with the strongest appearance at the middle fractions then faded reaching a very faint band in fraction B6 (Fig. 6 A \& B). On the contrary, fractions B1-B6 produced from the tail protein homogenate did not show any bands at the $\sim 75 \mathrm{kDa}$ range (Fig. 6C).

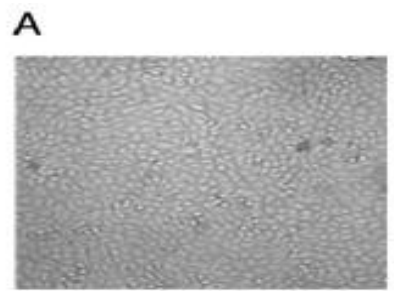

B
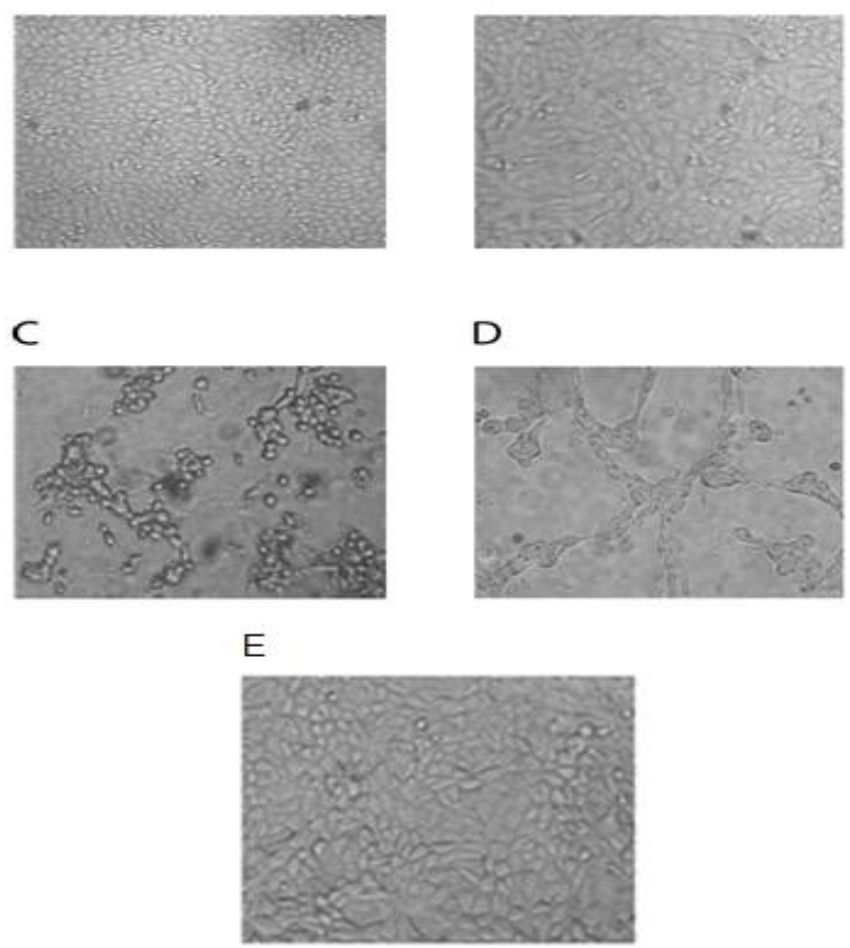

Fig (4): Cell Morphology of HepG2 cells after incubation with crude spine protein homogenate at 100X magnification power. (A) Normal HepG2 cells in the presence of media only. (B) HepG2 cells after incubation with the control; 10\% glycerol. (C) HepG2 cells after incubation with $1000 \mu \mathrm{g} / \mathrm{ml}$ crude venom protein homogenate showing cells lost attachment and had roundshaped morphology. (D) HepG2 cells after incubation with $500 \mu \mathrm{g} / \mathrm{ml}$ crude spine protein homogenate showing cells lost attachment and had round- shaped morphology. (E) HepG2 cells after incubation with $500 \mu \mathrm{g} / \mathrm{ml}$ crude tail protein homogenate showing normal cell morphology. 
A

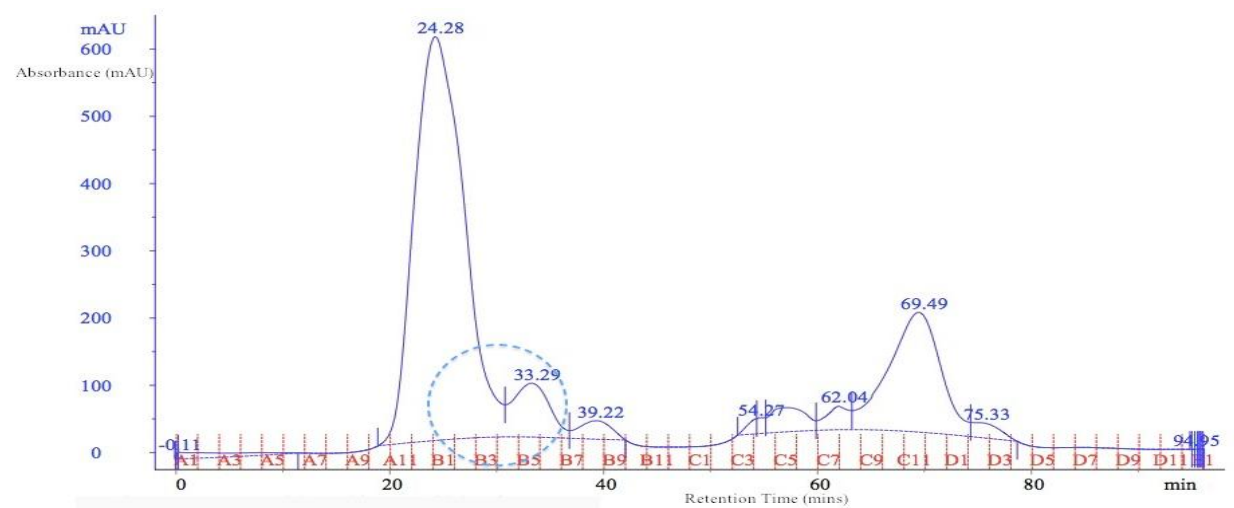

B

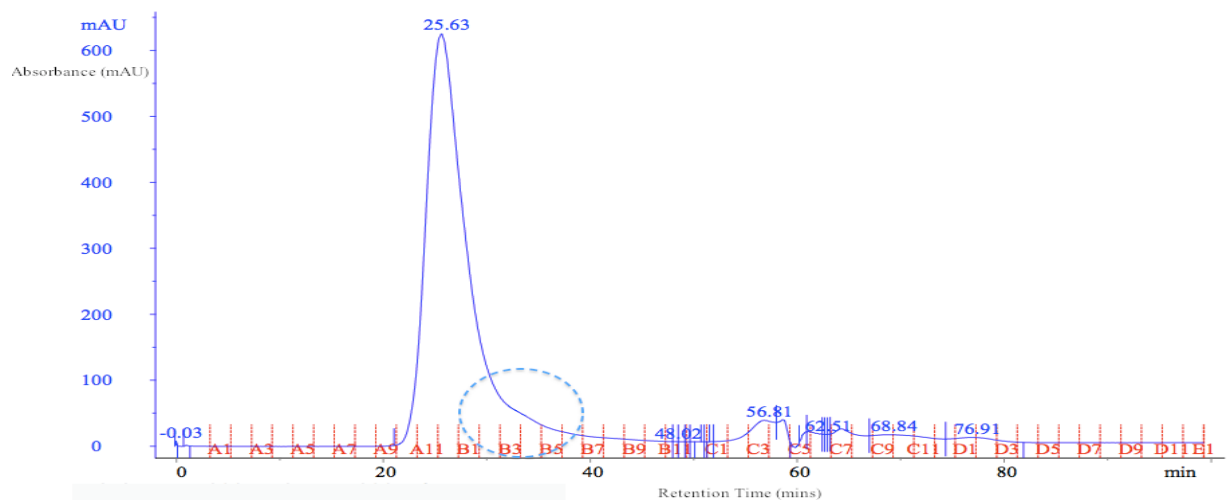

Fig (5): Size Exclusion chromatograms of the spine and tail crude protein homogenates. Fractionation of the protein homogenates was done to get different fractions having proteins of different sizes for the protein homogenate. Fractionation of spine homogenate (A) yielded 48 fractions from A1 through A12, B1 through B12, C1 through C12 and D1 through D12. Fractions B1- B6, encircled, contain the venom band and have cytotoxic effects on HepG2 cells. Fractionation of tail homogenate (B) yielded 48 fractions from A1 through A12, B1 through B12, C1 through C12 and D1 through D12. Fractions B1, B2, B3, B4, B5 and B6, encircled, show no peaks in comparison to spine homogenate and have no cytotoxic effects on HepG2 cells.
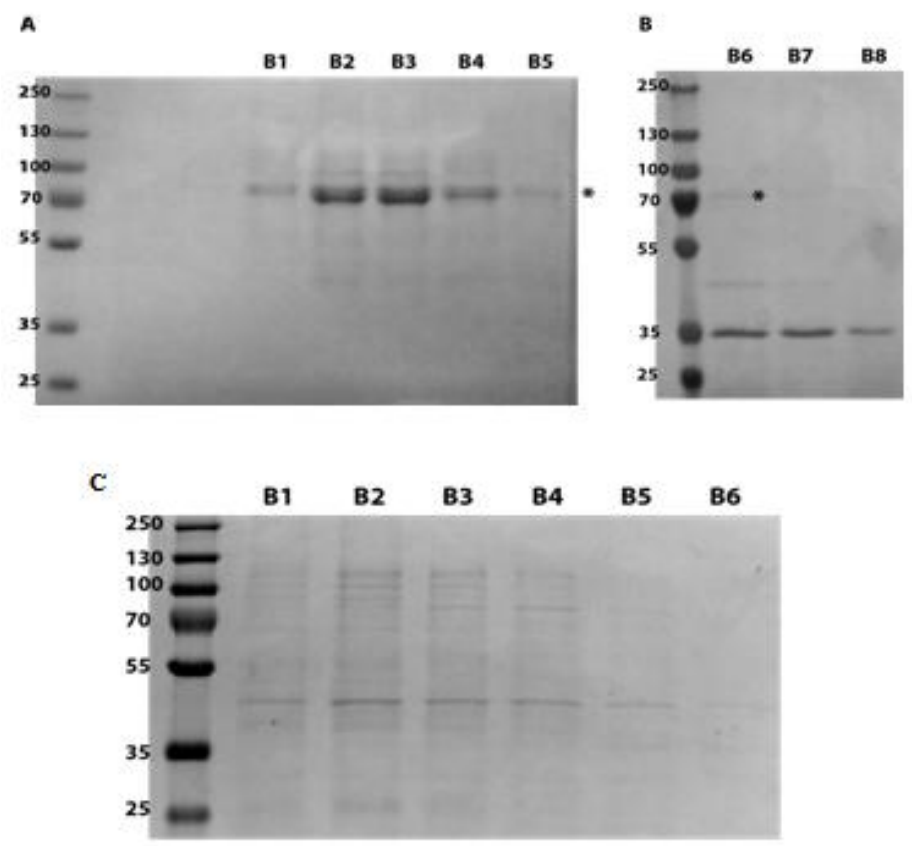

Fig (6): Banding pattern of the spine and tail crude protein homogenate fractions. (A) SDS-PAGE displaying the protein pattern of fractions B1, B2, B3, B4 and B5 as well as the protein ladder in the first lane. The venom band is shown very clearly in this SDS at $\sim 75 \mathrm{kDa}$ range. (B) SDS-PAGE displaying the protein pattern of fractions B6, B7 and B8 where there is a very faint venom band appearing in B6 and in fractions B7 and B8 a complete disappearance of the venom band. (C) SDS-PAGE displaying the protein pattern of fractions B1, B2, B3, B4, B5 and B6, the SDS showed the absence of the venom protein band at $\sim 75 \mathrm{kDa}$. 
Cytotoxic effects of the Pterois miles spine protein fractions on HepG2 cells

Cytotoxicity testing was done for all the 48 fractions of the spine protein homogenate using the HepG2 cells. Only six fractions, B1, B2, B3, B4, B5 and B6, produced from the spine homogenate showed cytotoxic effects resulting in a significant percentage of HepG2 cell death (Fig. 7A). The cell death caused by these six spine fractions ranged from $70 \%(\mathrm{p}<0.001)$ to $40 \%$ $(\mathrm{p}<0.05)$.

Pterois miles'venom protein proposed to be a potential anti-cancer agent

Cytotoxicity of the six spine fractions, B1 through B6, was compared to the corresponding tail fractions. Under the same conditions, the corresponding fractions, B1 through B6, of the tail crude homogenate did not show any cytotoxicity and instead they boosted the survival of the cells (Fig. 7B). The same spine fractions, B1-B6, were shown previously to exclusively contain the proposed venom protein band at $\sim 75 \mathrm{kDa}$ (Fig. 6). As illustrated in Fig. 7A, fraction B6 has the lowest cytotoxic capability among the six fractions; also this same fraction B6 has shown earlier to have the least concentration of the proposed venom protein band at $\sim 75$ kDa (Fig. 6). HepG2 cell death was also morphologically very clear when the cells were treated with the six spine fractions, B1-B6, if compared to the cells treated with the same corresponding tail fractions (Fig 8).

\section{Discussion}

Animal venoms are widely acknowledged to be an outstanding resource for discovering new bioactive compounds and biotechnological products for medical use. Despite being considered as one of the promising untapped resources of bioactive compounds, fish venom research is inadequately represented in the literature ${ }^{[23]}$. By giving an insight on the identity of the Red Sea lionfish, Pterois miles, venom and its cytotoxic effects on HepG2 cancer cells, this study tried to make further insights to the fish venom research.
A

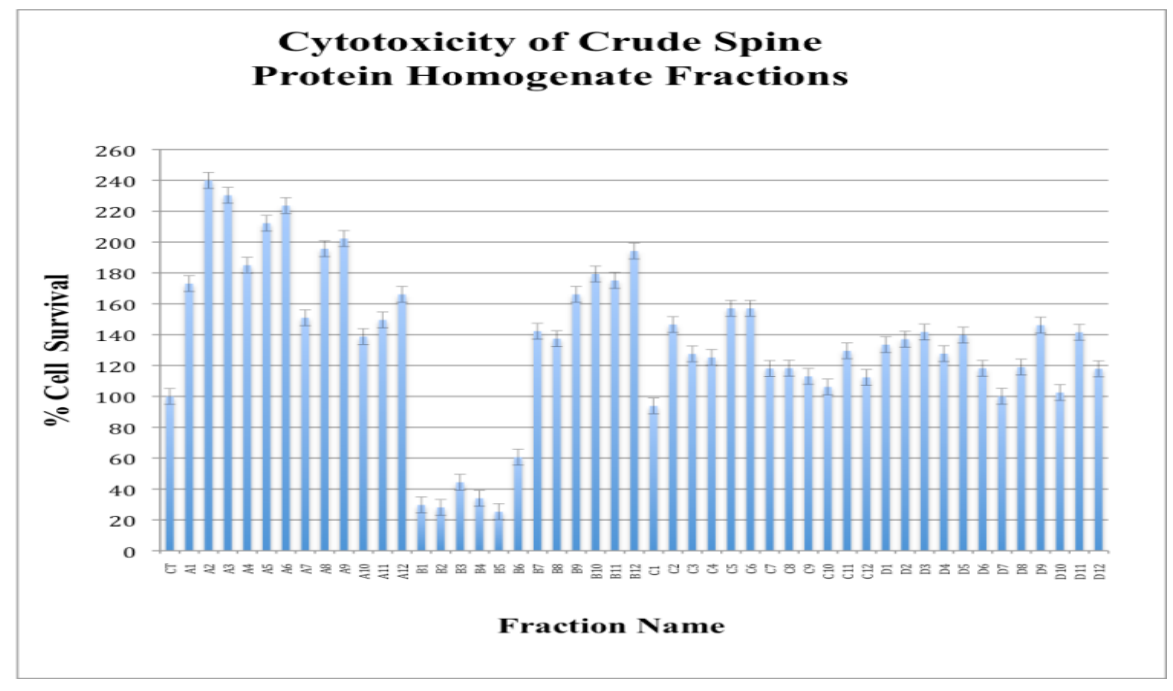

B

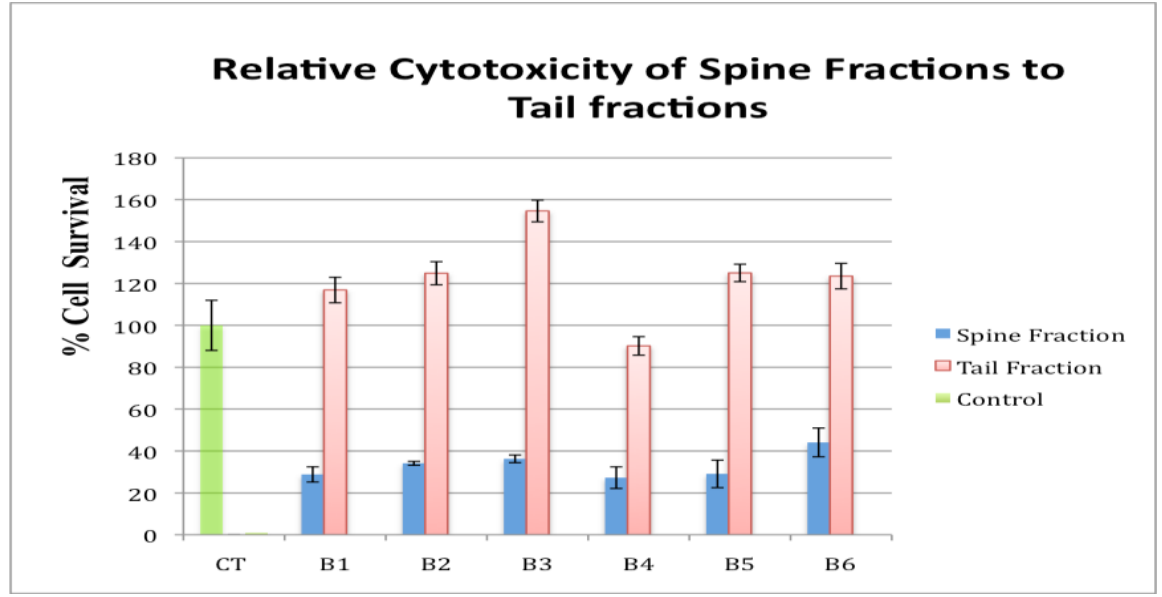

Fig (7): Cytotoxicity of the eluted protein fractions after size exclusion chromatography. (A) Cell survival of the HepG2 cells after exposure to all the fractions of the crude spine protein homogenate, showing the cytotoxicity of only six fractions: B1, B2, B3, B4, B5 and B6. Fraction names are A1 through A12, B1 through B12, C1 through C12 and D1 through D12. (B) Differential cytotoxicity of six effective fractions of the eluted venom protein in comparison to the same fractions from the eluted tail fractions. CT; Control HepG2 cells with the control (50mM sodium phosphate buffer and $10 \%$ glycerol). Values are the means of three trials \pm SD. 
A

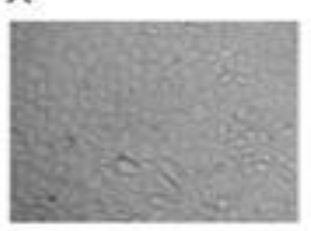

c

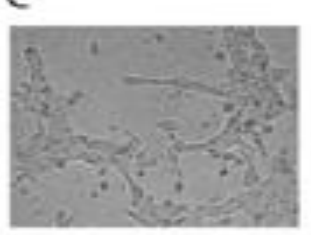

E

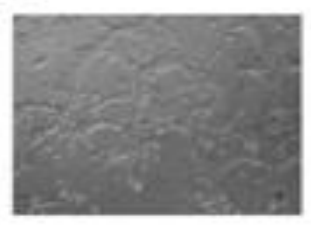

G

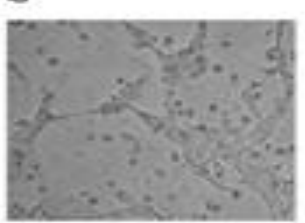

B

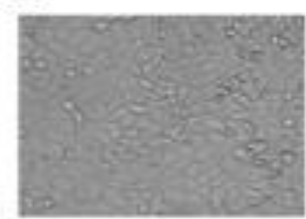

D

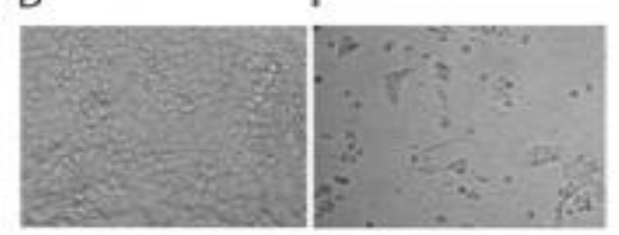

F

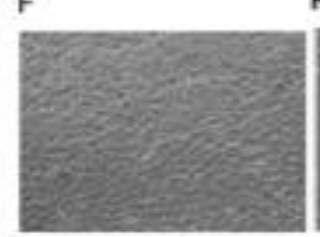

K

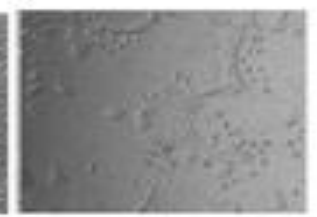

$\mathrm{H}$

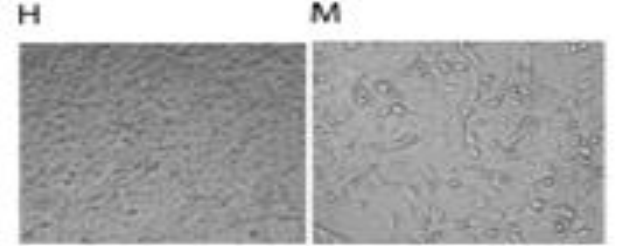

J

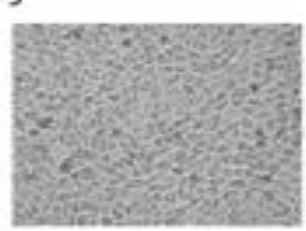

L.

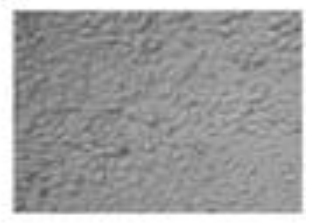

N

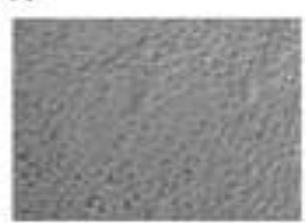

Fig (8): Cell Morphology of HepG2 cells after incubation with the six effective spine fractions in comparison to the six tail fractions at 100X magnification power. (A) Normal HepG2 cells in the presence of media only. (B) HepG2 cells after incubation with the control; $10 \%$ glycerol and $1 \mathrm{mM} \mathrm{NaHPO}_{4}$. (C) (E) (G) (I) (K) (M) HepG2 cells after incubation with crude spine protein homogenate fractions; B1, B2, B3, B4, B5 and B6 respectively. They show obvious change in the cell morphology. (D) (F) (H) (J) (L) (N) HepG2 cells after incubation with crude tail protein homogenate fractions; B1, B2, B3, B4, B5 and B6 respectively. No morphological changes on the cells were observed.

The approach followed in this study intended to unravel the identity of the venom protein composition of the spine with venomous structure, to that of the caudal fin rays (the tail), a non venomous structure. SDS-PAGE was used to compare the protein profile of the spine crude homogenate to that of the tail crude homogenate. The bony matrix of the spines and tail share the same evolutionary developmental origin therefore, using the crude homogenate of the tail provides an appropriate baseline from the venomous proteins that are exclusively found in the spine can be detected ${ }^{[24]}$. The results of SDS PAGE showed two exclusive protein bands in the spine homogenate; a $\sim 75 \mathrm{kDa}$ and a $\sim 35 \mathrm{kDa}$ bands (Fig. 1). The $75 \mathrm{kDa}$ band is very intense and obvious that stands very specific to the spine suggesting a high concentration of this protein in the dorsal spine tissues. Moreover, it was documented that the protein venom of Pterois volitans (the Pterois miles sister species) and Pterois antennata has the molecular weight of $\sim 75 \mathrm{kDa}$ ${ }^{[10]}$. Based on those two factors, it was reasonable to suspect that the $75 \mathrm{kDa}$ band is in fact the venom protein; accordingly, the $75 \mathrm{kDa}$ band was chosen to undergo a mass spectrometric analysis.
As expected, the mass spectrometry of this band showed a high degree of homology to the venom of Pterois volitans and Pterois antennata providing strong evidence of its venomous nature. The fact that this band was only present in the spine homogenate and was distinctly absent in the tail homogenate confirmed that the tail is non-venomous and that venom proteins are only expressed in integument surrounding the anti-predatory spines. Thus, through this set of experiments, it is reasonable to suggest with strong confidence that this 75 $\mathrm{kDa}$ band is the venom protein of Pterois miles. To the best of our knowledge, this is the first study to investigate and identify the venom protein of the Red Sea lionfish, Pterois miles.

It is very well known that the tumor derived cell lines are considered one of the most well-known and effective systems for the evaluation of new anti-cancer candidates for use in humans ${ }^{[25]}$. Specifically, the HepG2 cell lines have been frequently used in cytotoxicity assays testing venoms and venom components of various natures ${ }^{[20,26]}$. Therefore, the MTT assay was used in this study to evaluate the cytotoxicity of the spine crude protein homogenates and fractions on HepG2 cancer cell lines. 
As detailed in Figure 3, treating the HepG2 cells with various concentrations of the spine samples resulted in cell death that reached $78 \% \quad(\mathrm{p}<0.001)$ at a high concentration of $1000 \mu \mathrm{g} / \mathrm{ml}$. Even at very low concentration $(3.9 \mu \mathrm{g} / \mathrm{ml})$, the spine crude homogenate caused a remarkable amount of cell death of about $42 \%$ (p-value $<0.001$ ), which suggested a great potency for the crude spine homogenate (Fig. 3). On observing the HepG2 cells incubated with the spine homogenates under the inverted microscope, various morphological changes proved the cell death. The HepG2 normally appeared under the inverted microscope as a one continuous attached sheet of epithelial cells, as it is the case with the untreated and the control treated cells. However, after incubation with the crude spine homogenate, the cells became more rounded and detached from each other (Fig. 4). To confirm that the anti-cancer activity resulted from a bioactive compound that is found exclusively in the spine homogenate, equal concentrations of the tail homogenates were tested for their cytotoxic effect under the same conditions and showed no cytotoxic effects.

In an attempt to identify the cytotoxic component(s) from the spine crude homogenate, fractionation of the spine crude homogenate was done and the fractions were tested individually for possible cytotoxicity. Size exclusion chromatography was done to the spine crude homogenate which resulted in protein fractions of different sizes. This fractionation was also done to the tail crude homogenate which didn't show any cytotoxicity on HepG2 cells, hence it was after that considered as a negative control. The resulting chromatograms for both homogenates revealed some general similarities, which were consistent with the previous SDS PAGE results (Fig. 1). However, two distinct regions stand very clear as the showed differences between the spine and tail homogenates. The first region included fractions B1 through B9 (a high molecular weight region) and the second region included fractions C3 through D3 (a low molecular weight region). Since the HepG2 cytotoxicity was only induced by the spine homogenate, it was hypothesized that the cytotoxicity of the spine crude homogenate would be generated by one or more components of the two regions mentioned above in the spine homogenate.

To look into this hypothesis, all fractions of the spine homogenate were tested for cytotoxicity on HepG2 cells. Only six fractions from B1 through B6 in the spine homogenate caused cell death (Fig. 7A), which was not the case for the similar tail fractions (Fig. 7B). Morphological changes of the HepG2 cells also confirmed cell death in case of the spine homogenate fractions. It was also observed that the rest of the spine fractions, other than fractions B1-B6, actually caused a boost in cell survival. As one would imagine, this boost in cell survival could have happened as a result of the presence of extra protein contents in these fractions that act as extra nutrients to favor cell survival and proliferation. Although the region that showed different chromatogram peaks between the spine and the tail homogenates extended from fractions B1 to B9, only fractions B1 through B6 showed significant cytotoxicity. Spine fractions B1 through B5 has actually shown to contain the purported venom protein, the $75 \mathrm{kDa}$ band, and a very faint band was observed in fraction B6 as was confirmed via SDS-PAGE, unlike the same tail fractions. Once the $75 \mathrm{kDa}$ band started to disappear and the 35 $\mathrm{kDa}$ band started to appear the cytotoxic effect was tremendously decreased then lost as was clear in Figure 9. In addition to that, the HepG2 cells treated with the B6 fraction showed the least cell death in comparison to the other five spine fractions, their morphology has more in common with the normal cells (Fig. 8). It is worth noting here that the region including fractions $\mathrm{C} 3$ through D3 of the spine homogenate, a low molecular weight region, did not show any cytotoxic effect on HepG2 cells. Based on these data, it is reasonable to theorize that the venom protein of the Red Sea lion fish Pterois miles, purported to be at the $75 \mathrm{kDa}$ range, could be the bioactive component that resulted in the cytotoxicity of the HepG2 cancer cell lines.

In conclusion, this study proposes the venom protein of the Red Sea lionfish species, Pterois miles, to have the molecular weight of $75 \mathrm{kDa}$. A combination of different experiments also showed the potent cytotoxic effects of the spine homogenates on the HepG2 cells suggesting the venom protein to be a potential anti-cancer compound. These results certainly deserve further investigations to confirm the identity of the venom protein and to unravel its cytotoxic mechanism. Having a real functioning protein that exerts an in-vitro anti-cancer effect increases the probability that it could have an invivo effect as well.

\section{Acknowledgement}

The authors are thankful to Dr. Asma Amleh for kindly providing us with the HepG2 cancer cell line.

\section{Conflict of interest}

The authors declare that there are no conflicts of interest.

\section{References}

1) Knasmüller, S., Mersch-Sundermann, V., Kevekordes, S., Darroudi, F., Huber, W. W., Hoelzl, C., Bichler, J. and Majer, B. J. (2004). Use of human-derived liver cell lines for the detection of environmental and dietary genotoxicants; Current state of knowledge. Toxicology. 198:315-328.

2) Felczykowska, A., Bloch, S. K., NejmanFaleńczyk, B. and Barańska, S. (2012). Metagenomic approach in the investigation of new bioactive compounds in the marine environment. Acta Biochim Pol. 59(4):501-505.

3) Simmons, T. L., Andrianasolo, E., Mcphail, K., Flatt, P. and Gerwick, W. H. (2005). Marine natural products as anticancer drugs. Mol Cancer Ther. 4:333-342.

4) Reza, R. and Singh, G. (2010). Heavy metal contamination and its indexing approach for river water. Int $J$ Environ Sci Tech. 7(4):785-792. doi:10.1007/BF03326187. 
5) Stonik, V. A. and Fedorov, S. N. (2014). Marine low molecular weight natural products as potential cancer preventive compounds. Mar Drugs. 12(2):636-671. doi:10.3390/md12020636.

6) Martins, A., Vieira, H., Gaspar, H. and Santos, S. (2014). Marketed Marine Natural Products in the Pharmaceutical and Cosmeceutical Industries: Tips for Success. 2014:1066-1101. doi:10.3390/ md12021066.

7) Regalado, E. L., Martínez, J. R. and Laguna, A. (2010). Marine sponges as a source of new bioactive substances. Revista electrónica de la Agencia de Medio Ambiente.

8) Smith, W. L. and Wheeler, W. C. (2006). Venom evolution widespread in fishes: A phylogenetic road map for the bioprospecting of piscine venoms. $J$ Hered. 97(3):206-217. doi:10.1093/jhered/esj034.

9) Sivan, A. (2011). New perspectives in plastic biodegradation. Curr Opin Biotechnol. 22(3):422426. doi:10.1016/j.copbio.2011.01.013.

10) Kiriake, A. and Shiomi, K. (2011). Some properties and cDNA cloning of proteinaceous toxins from two species of lionfish (Pterois antennata and Pterois volitans). Toxicon. 58(67):494-501. doi:10.1016/j.toxicon.2011.08.010.

11) Wodarz, A. and Gonzalez, C. (2006). Connecting Cancer to the Asymmetric Division of Stem Cells. Cell, 124(6):1121-1123. doi:10.1016/j.cell.2006. 03.004 .

12) Debelius, B., Forja, J. M., Delvalls, T. A. and Lubián, L. M. (2009). Toxicity of copper in natural marine picoplankton populations. Ecotoxicology. 18(8):1095-1103. doi:10.1007/s10646-009-0377-3.

13) Linnaeus, C. (1758). Systema Naturae per Regna Tria Naturae. 2 Vols. doi:10.1007/s13398-0140173-7.2.

14) Kochzius, M., Söller, R., Khalaf, M. A. and Blohm, D. (2003). Molecular phylogeny of the lionfish genera Dendrochirus and Pterois (Scorpaenidae, Pteroinae) based on mitochondrial DNA sequences. In: Molecular Phylogenetics and Evolution. 28:396-403. doi:10.1016/S10557903(02)00444-X.

15) Hamner, R. M., Freshwater, D. W. and Whitfield, P. E. (2007). Mitochondrial cytochrome $\mathrm{b}$ analysis reveals two invasive lionfish species with strong founder effects in the western Atlantic. J Fish Biol. 71(SUPPL. B):214-222. doi:10.1111/j.10958649.2007.01575.x.
16) Morris, J. A., Akins, J. L., Barse, A., Cerino, D. and Freshwater, D. W. (2008). Biologia y Ecologia del Pez Leon Invasor, Pteoris miles y Pterois volitans Biologie et Ecologie de Rascasses volantes Invasives, Pteoris miles et Pterois volitans. Mar Ecol. 29:1-6.

17) Church, J. E. and Hodgson, W. C. (2002). The pharmacological activity of fish venoms. Toxicon. 40(8): 1083-1093. 0101(02)00125.

18) Balasubashini, M. S., Karthigayan, S., Somasundaram, S. T., Balasubramanian, T., Viswanathan, P. and Menon, V. P. (2006). In vivo and in vitro characterization of the biochemical and pathological changes induced by lionfish (pterios volitans) venom in mice. Toxicol Mech Methods. 16:525-531. doi:10.1080/15376510600803573.

19) Laemmli, U. K. (1970). Cleavage of Structural Proteins during the Assembly of the Head of Bacteriophage T4. Nature. 227(5259):680-685. doi:10.1038/227680a0.

20) Helmholz, H., Ruhnau, C., Schütt, C. and Prange, A. (2007). Comparative study on the cell toxicity and enzymatic activity of two northern scyphozoan species Cyanea capillata (L.) and Cyanea lamarckii (Péron \& Léslieur). Toxicon. 50(1):53-64. doi:10.1016/j.toxicon.2007.02.014.

21) Dawson, J. R., Adams, D. J. and Wolf, C. R. (1985). Induction of Drug Metabolizing Enzymes in Human Liver Cell Line Hep G2. 183:1985. doi:10.1016/0014-5793(85)80780-8.

22) Franchi, L., Muñoz-Planillo, R. and Núñez, G. (2012). Sensing and reacting to microbes through the inflammasomes. Nat Immunol. 13(4):325-332. doi:10.1038/ni.2231.

23) Ziegman, R. and Alewood, P. (2015). Bioactive components in fish venoms. Toxins (Basel). 7(5):1497-1531. doi:10.3390/toxins7051497.

24) Nguyen, L. and Pieters, J. (2009). Mycobacterial subversion of chemotherapeutic reagents and host defense tactics: challenges in tuberculosis drug development. Апnи Rev Pharmacol Toxicol. 49:427453. doi:10.1146/annurev-pharmtox-061008-103123.

25) Sharma, S. V., Haber, D. A. and Settleman, J. (2010). Cell line-based platforms to evaluate the therapeutic efficacy of candidate anticancer agents. Nat Rev Cancer. 10(4):241-253. doi:10.1038/nrc2820.

26) Heinen, T. E. and Gorini da Veiga, A. B. (2011). Arthropod venoms and cancer. Toxicon. 57(4):497511. doi:10.1016/j.toxicon.2011.01.002. 